\title{
PELAKSANAAN PIDANA MATI DI INDONESIA DALAM PERSPEKTIF HAK ASASI MANUSIA
}

\author{
Marwin \\ Fakultas Syariah UIN Raden Intan Lampung \\ J1. Letkol Endro Suratmin Sukarame Bandar Lampung \\ Email: marwin@radenintan.ac.id
}

\begin{abstract}
Abstak: Selain perdebatan tentang perlu atau tidaknya pidana mati, perdebatan juga terjadi berkenaan dengan cara pelaksanaan pidana mati itu sendiri. Perdebatan tentang alasan manusiawi atau tidaknya cara pelaksanaan pidana mati tersebut. Pasal 11 KUHP menyatakan bahwa pidana mati dijalankan oleh algojo ditempat penggantungan, dengan menggunakan sebuah jerat dileher terpidana dan mengikatkan jerat itu pada tiang penggantungan dan menjatuhkan papan tempat orang itu berdiri. Ketentuan Pasal 11 KUHP diubah oleh Undang-Undang Nomor 02/Pnps/1964 juncto Undang-Undang Nomor 5 Tahun 1969 Tentang Tata Cara Pelaksanaan Pidana Mati yang Dijatuhkan oleh Pengadilan di Lingkungan Pengadilan Umum dan Militer. Dalam Pasal 1 dinyatakan bahwa pelaksanaan pidana mati yang dijatuhkan oleh pengadilan di lingkungan Peradilan Umum atau Peradilan Militer dilakukan dengan ditembak sampai mati. Ketentuan ini, selanjutnya telah disempurnakan dengan diberlakukannya Peraturan Kepala Kepolisian Republik Indonesia Nomor 12 Tahun 2010 Tentang Tata Cara Pelaksanaan Pidana Mati.

Putusan Mahkamah Konstitusi Nomor 21/PUU-VI/2008, menyatakan bahwa cara pelaksanaan pidana mati dengan ditembak sampai mati sebagaimana diatur dalam Undang-Undang Nomor 02/Pnps/1964 tidak bertentangan dengan UUD 1945, yang dengan demikian dapat diartikan bahwa pelaksanaan pidana mati dengan ditembak sampai mati tidak melanggar HAM khususnya hak untuk tidak disiksa sebagaimana diatur dalam Pasal 28I ayat (1) UUD 1945. Pelaksanaan pidana mati dengan cara ditembak, memang menimbulkan rasa sakit, namun rasa sakit yang dialami oleh terpidana tidak dapat dikatakan sebagai suatu bentuk penyiksaan terhadap terpidana. Rasa sakit dalam pelaksanaan pidana mati akan tetap dirasakan oleh terpidana.
\end{abstract}

Kata kunci: pelaksanaan pidana mati, hak asasi manusia.

\section{A. Pendahuluan}

Setidaknya dalam kurun waktu antara tahun 1992-1997, sejumlah lebih kurang 12 orang dijatuhi pidana mati karena melakukan tindak pidana pembunuhan, pencurian dengan kekerasan, narkotika, dan subversi. Data tersebut sebagaimana dimuat harian Kompas, hari Rabu 14 Mei $1997 .{ }^{1}$ Selama era reformasi sejak 1998 hingga Desember 2009, terpidana mati yang telah dieksekusi sebanyak 21 orang. Tiga besar kasus yang melatari eksekusi mati adalah pembunuhan (13 kasus), narkoba/psikotropika (5 kasus), dan

1 Bambang Waluyo, 2000, Pidana dan Pemidanaan, Sinar Grafika, Jakarta, hlm 1314. 
terorisme (3 kasus). Tahun 2008 merupakan tahun paling banyak dilakukan eksekusi mati, yakni 10 orang dengan latar belakang kasus pembunuhan (5 orang), narkoba/ psikotropika (2 orang), dan terorisme (3 orang). ${ }^{2}$

Imparsial menyebutkan sejak tahun 1998 sampai tahun 2009 terdapat 119 orang dijatuhi vonis mati dari otoritas Pengadilan, mulai dari Pengadilan Negeri hingga Mahkamah Agung. Sebanyak 101 vonis mati dijatuhkan Pengadilan Negeri, Pengadilan Tinggi sebanyak 2 vonis mati, Pengadilan Militer 2 vonis mati, Mahkamah Agung 12 vonis mati, dan tidak diketahui 1 vonis mati. Kasus vonis mati terbanyak adalah narkoba dan psikotropika (72 kasus), pembunuhan (38 kasus), dan terorisme (9 kasus).

Cara pelaksanaan pidana mati di Indonesia telah beberapa kali diubah, yaitu menurut WvS 1915 dilaksanakan dengan digantung, menurut Оsamu Gunrei Nomor 1 tanggal 2 Maret 1942 dilaksanakan dengan ditembak mati, menurut WvS 1915 juncto Staatblad 1945 Nomor 123 dilaksanakan seperti dalam acara militer dengan ditembak mati, dan menurut KUHP juncto UndangUndang Nomor 1 Tahun 1946, Undang-Undang Nomor 73 Tahun 1958, dan Undang-Undang Nomor 02/Pnps/1964 dilaksanakaan dengan ditembak sampai mati. ${ }^{3}$

Pasal 11 KUHP menyatakan pidana mati dijalankan oleh algojo ditempat penggantungan, dengan menggunakan sebuah jerat dileher terpidana dan mengikatkan jerat itu pada tiang

2 Tim Imparsial, 2010, Menggugat Hukuman Mati Di Indonesia, Imparsial, Jakarta, hlm 45.

3 Bambang Poernomo, 1982, Hukum Pidana Kumpulan Karangan Ilmiah, Bina Aksara, Jakarta, hlm 16. penggantungan dan menjatuhkan papan tempat orang itu berdiri. Ketentuan Pasal 11 KUHP diubah oleh Undang-Undang Nomor 02/Pnps/1964 tentang Tata Cara Pelaksanaan Pidana Mati yang Dijatuhkan oleh Pengadilan di Lingkungan Pengadilan Umum dan Militer. Dalam Pasal 1 dinyatakan bahwa pelaksanaan pidana mati yang dijatuhkan oleh pengadilan di lingkungan peradilan umum atau peradilan militer dilakukan dengan ditembak sampai mati.

\section{B. Pembahasan}

1. Bentuk-Bentuk Pelaksanaan Pidana Mati

Tiap-tiap negara memiliki metode pelaksanaan pidana mati yang berbedabeda, termasuk di Indonesia. Bahkan pada masa lalu, metode eksekusi mati yang berlaku di tiap-tiap daerah di Indonesia juga berbeda-beda, sesuai dengan hukum adat yang berlaku di tiap-tiap daerah yang bersangkutan. Jauh sebelum Belanda menjajah Indonesia, pidana mati memang sudah diterapkan oleh kerajaan atau sukusuku yang ada di Indonesia pada waktu itu. $^{4}$

Dahulu kala diberbagai negara juga dikenal berbagai macam pelaksanaan model hukuman mati, antara lain: potong leher dengan pisau besar (guillotine), digantung, dipukul sampai mati, dibakar, dikubur hidup-hidup, ditenggelamkan, dirajam (dilempar dengan batu sampai mati), dan macammacam cara lainnya. ${ }^{5}$ Seiring dengan perkembangan zaman, pelaksanaan

4 Bambang Sugeng Rukmono, 2006, Hakikat Pelaksanaan Hukuman Mati Ditinjau Dari Perspektif Hak Asasi Manusia, PT RajaGrafindo Persada, Jakarta, hlm 119.

${ }^{5}$ Bambang Sugeng Rukmono, Hakikat Pelaksanaan..., hlm 122. 
pidana mati mengalami perubahan, misalnya dengan cara ditembak, sengatan listrik, ditempatkan dalam kamar berisi gas beracun, atau disuntik mati. ${ }^{6}$

Muhammad Luthfie Hakim dalam keterangan tertulis yang disampaikan dalam sidang yudicial review UndangUndang Nomor 02/Pnps/1964 tentang Tata Cara Pelaksanaan Pidana Mati yang Dijatuhkan Pengadilan Dilingkungan Peradilan Umum dan Militer, yang diserahkan oleh Pemohon $^{7}$ dan diterima oleh Kepaniteraan Mahkamah Konstitusi pada 25 September 2008, menyatakan beberapa bentuk eksekusi pidana mati yang masih diterapkan di dunia, antara lain: ${ }^{8}$

a. Digantung (hanging), berlaku di beberapa Negara Timur Tengah seperti Jordan, Irak, Iran, negara-negara asia seperti India, Malaysia, Singapura, Jepang. Di Negara Amerika Serikat terdapat hanya di dua negara bagian saja yang menjadikan hukuman gantung sebagai opsi cara menghukum mati, yaitu Negara Bagian Washington dan New Hampshire, dan masih banyak lagi dipraktikkan di negara-negara lain;

b. Dipenggal pada leher (decapitation), berlaku di beberapa Negara Timur

${ }^{6}$ Bambang Sugeng Rukmono, Hakikat Pelaksanaan..., hlm 122.

7 Pemohon yudicial review UndangUndang Nomor 2/Pnps/1964 tentang Tata Cara Pelaksanaan Pidana Mati yang Dijatuhkan Pengadilan Dilingkungan Peradilan Umum dan Militer, adalah tiga orang terpidana mati kasus bom Bali II, yaitu Amrozi bin Nurhasyim, Ali Ghufron bin Nurhasyim, dan Abdul Azis alias Imam Samudra.

8 Putusan Mahkamah Konstitusi Nomor 21/PUU-VI/2008, www.mahkamahkonstitusi.go.id, diunduh tgl 19 September 2018, hlm 29-30.
Tengah antara lain di Arab Saudi, Iran, Qatar, dan Yaman;

c. Ditembak (shooting), berlaku antara lain di Negara Libya, Palestina, Yaman, Afghanistan, Vietnam, Republik Rakyat China, Taiwan, Indonesia dan beberapa negara lainnya. Tembakan dilakukan pada kepala bagian belakang atau leher, atau jantung terpidana;

d. Strum listrik (electrocution atau the electric chair), berlaku sebagai suatu opsi hukuman mati di Amerika Serikat untuk beberapa negara bagian saja, yaitu Alabama, Florida, South Carolina, Kentucky, Tennessee dan Virginia;

e. Ruang gas (gas chamber), berlaku di Amerika Serikat untuk beberapa negara bagian, yaitu Colorado, Nevada, Missisippi, New Mexico, North Carolina dan Oregon, serta menjadi cara alternatif menghukum mati di beberapa negara bagian lainnya;

f. Suntik Mati (lethal injection), metode hukuman ini mulai dikenal pada abad 20 yang ditemukan dan dikembangkan oleh Negara Amerika Serikat, diterima oleh lebih dari 30 negara bagiannya. Cara ini juga mulai dianut oleh RRC (1997), Guatemala (1950, Philipina (1999), Thailand (2003), dan Taiwan (2005).

Lebih lanjut Luthfie menyatakan, cara hukuman mati dengan ditembak memang merupakan cara yang paling banyak digunakan di negara-negara yang masih menerapkan hukuman mati. Hingga tahun 2000, ada 69 negara yang memberlakukan tata cara ditembak mati. Namun, tata cara ini cenderung untuk berganti ke tata cara lain yang dipandang lebih baik. Negara Cina misalnya, kini menerapkan dua jenis metode hukuman mati, yaitu tembak mati dan suntik mati. Demikian 
halnya peralihan mulai diterapkan oleh negara Guatemala dan Thailand dari hukuman ditembak mati ke suntik mati. Di Amerika Serikat sudah hampir semua negara bagian memberlakukan tata cara suntik mati.

Penjelasan tentang berbagai macam pelaksanaan pidana mati, juga digambarkan oleh Bambang Sugeng Rukmono.

\section{a. Injeksi Mati (Lethal Injection) ${ }^{10}$}

Pelaksanaan pidana mati dengan cara disuntik masih diterapkan di beberapa negara bagian Amerika Serikat. Prosesi Pelaksanaan dilakukan dengan cara tahanan dibawa ke ruang eksekusi, didudukan atau dibaringkan dengan dua suntikan dengan selang yang sudah tertempel di tangannya. Selang tersebut terhubung dengan tabung-tabung yang dapat setiap saat disuntikkan melalui tempat di mana eksekusi akan dilakukan. Ketika proses eksekusi dimulai, satu atau lebih algojo memberikan dosis mematikan yang tidak diketahui oleh publik untuk diberikan kepada terpidana. Dosis tersebut kemudian disuntikan melalui mesin atau adakalanya disuntikan secara manual.

b. Kursi Listrik (Electrocution) ${ }^{11}$

Metode ini diciptakan oleh Harold P. Brown, yang dipekerjakan oleh Thomas Edison guna menyelidiki penggunaan listrik untuk eksekusi. Dalam eksekusi dengan kursi listrik, terpidana diikatkan di kursi dengan tali logam dan spons basah ditempatkan di

9 Putusan Mahkamah Konstitusi Nomor 21/PUU-VI/2008..., hlm 31.

${ }^{10}$ Bambang Sugeng Rukmono, Hakikat Pelaksanaan..., hlm. 125-127

${ }^{11}$ Bambang Sugeng Rukmono, Hakikat Pelaksanaan..., hlm. 127 kepala untuk membantu konduktivitas. Elektroda ditempatkan pada kepala dan kaki untuk membuat sirkuit tertutup. Arus listrik pertama sebesar 2000 volt dialirkan selama 15 detik. Arus pertama ini ditujukan untuk menghentikan jantung sehingga menyebabkan ketidaksadaran. Arus kedua dialirkan sehingga menyebabkan kerusakan organ internal dan menjadikan tubuh terbakar. Kesemua aliran arus tersebut membuat terpidana pingsan untuk lebih meminimalisasi sakit dan penderitaan.

c. Kamar Gas (Gas Chamber $)^{12}$

Sebelum eksekusi, algojo memasuki kamar gas yang akan diisi gas potassium sianida (KCN) ke dalam kompartemen kecil terpidana di bawah kursi eksekusi. Setelah itu, terpidana dibawa dan diamankan ke kursi dalam ruang yang disegel. Kemudian algojo mengalirkan sejumlah asam sulfat pekat (H2SO4) melalui tabung yang mengarah ke kompartemen terpidana. Terpidana biasanya telah diingatkan untuk mengambil napas dalam-dalam guna mempercepat ketidaksadaran, namun kebanyakan terpidana menahan napas. Secara umum, eksekusi dengan kamar gas hidrogen sianida cukup menyakitkan dan tidak menyenangkan.

d. Eksekusi Regu Tembak (The Firing Squad $^{13}$

Metode eksekusi dengan regu tembak dianggap sebagai metode yang paling baik, karena caranya yang cukup layak. Dalam melakukan

12 Bambang Sugeng Rukmono, Hakikat Pelaksanaan..., hlm. 128

${ }^{13}$ Bambang Sugeng Rukmono, Hakikat Pelaksanaan..., hlm. 129 
eksekusi, salah satu penembak yang ada dari regu tembak diberikan peluru kosong untuk mengurangi rasa bersalah dan menguatkan mental. Tidak satu pun dari penembak tahu siapa yang memiliki peluru kosong. Hanya dua negara bagian Amerika Serikat yang menggunakan metode regu tembak, yaitu negara bagian Idaho dan negara bagian Oklahoma. Meskipun demikian, negara bagian Utah juga memiliki empat terpidana mati yang mendapatkan izin untuk memilih eksekusi oleh regu tembak.

e. Eksekusi Gantung (Hanging) ${ }^{14}$

Metode ini pernah digunakan Nazi dan menjadi bentuk yang paling umum digunakan sebelum tahun 1850-an. Ciri dari eksekusi ini adalah kematian yang lambat dan menyakitkan. Metode eksekusi gantung sangat popular di Iran. Dimana terpidana ditempatkan dalam posisi berdiri di tanah dengan simpul di leher. Kemudian tiang gantungan digerakkan dan diangkat ke atas, sehingga menyebabkan terpidana tercekik. Eksekusi gantung juga dilaksanakan di Inggris setelah tahun 1850-an, dengan mengikat simpul di leher terpidana dan kemudian menjatuhkannya untuk menjerat leher.

f. Eksekusi Penggal (Beheading) ${ }^{15}$

Eksekusi dengan cara penggal kepala, merupakan cara yang paling banyak dan masih umum digunakan, di beberapa negara yang menganut sistem hukum Islam. Negara Arab Saudi merupakan yang paling sering menggunakan metode ini. Eksekusi biasanya dilakukan pada Jumat

${ }^{14}$ Bambang Sugeng Rukmono, Hakikat Pelaksanaan..., hlm. 129-130

15 Bambang Sugeng Rukmono, Hakikat Pelaksanaan..., hlm. 130 malam di luar masjid utama kota setelah shalat. Hukuman mati ini biasanya dijatuhkan pada pelaku perkosaan, pembunuhan, kejahatankejahatan terkait narkoba, dan kemurtadan.

g. Eksekusi Guillotine ${ }^{16}$

Eksekusi mati dengan pisau yang dikenal dengan nama guillotine, bukanlah diciptakan oleh JosephIgnace Guillotine (1738-1814). Guillotine duduk pada sebuah komite yang menyetujui rancangan pisau eksekusi Antoine Louis (17231792). Alat eksekusi ini terdiri atas bingkai kayu besar dengan ruang di bagian bawah untuk leher terpidana mati. Sementara di bagian atas bingkai menggantung pisau miring besar yang akan dijatuhkan tepat di leher sehingga mengakibatkan kepala terpenggal. Metode resmi eksekusi mati Prancis sediri dibubarkan pada tahun 1981.

h. Eksekusi Rajam (Stoning) ${ }^{17}$

Eksekusi mati dengan cara rajam (stoning) dilakukan dengan melempar bat uke terpidana sampai mati. Terpidana pada metode eksekusi ini ditempatkan tidak bergerak untuk dilempari batu hingga mati. Metode ini popular dan banyak digunakan di negara-negara Islam. Di Iran eksekusi rajam digunakan untuk delik perzinaan dan kejahatan lainnya. Rajam dilakukan dengan menggunakan batu yang tidak boleh terlalu besar, untuk memastikan bahwa terpidana meninggal sesudah dihantam dengan batu kecil yang didefinisikan sebagai kerikil, dengan catatan tetap harus menyebabkan cedera parah.

${ }^{16}$ Bambang Sugeng Rukmono, Hakikat Pelaksanaan..., hlm. 131

${ }^{17}$ Bambang Sugeng Rukmono, Hakikat Pelaksanaan..., hlm. 132 
i. Eksekusi Garrote (Choked to Death) ${ }^{18}$

Metode eksekusi ini sekarang tidak lagi digunakan di negara manapun, meskipun pada praktiknya sering digunakan dalam latihan legion asing Prancis. Perangkat garrote pernah digunakan di Spanyol hingga dihapus pada tahun 1978, bersamaan dengan penghapusan penerapan pidana mati. Eksekusi terakhir dengan menggunakan garrote dilakukan terhadap Jose Luis Cerveto pada Oktober 1977. Pelaksanaan metode ini dilakukan dengan mendudukan terpidana mati di kursi dengan sejumlah ikatan di tubuh, tangan, dan kaki. Kemudian algojo memperketat band metal garrote di leher terpidana sehingga mengakibat terpidana tercekik dan meninggal dunia. Andorra menjadi negara tterakhir yang melarang penggunaan garrote sebagai metode eksekusi pidana mati pada tahun 1990 .

\section{Pelaksanaan Pidana Mati di Indonesia \\ Pelaksanaan pidana mati di} Indonesia, pada mulanya sebagaimana diatur dalam Pasal 11 KUHP. Pidana mati dijalankan oleh algojo di tempat gantungan dengan menjeratkan tali yang terikat di tiang gantungan pada leher terpidana, kemudian menjatuhkan papan tempat terpidana berdiri. Pelaksanaan pidana mati kemudian diubah oleh Undang-Undang Nomor 02/Pnps/1964, yaitu pidana mati yang dijatuhkan di lingkungan Peradilan Umum atau Peradilan Militer dilakukan dengan ditembak sampai mati. Alasan dilakukannya perubahan ini bahwa ketentuan-ketentuan yang

${ }^{18}$ Bambang Sugeng Rukmono, Hakikat Pelaksanaan..., hlm. 132 berlaku mengenai tata cara pelaksanaan pidana mati bagi orang-orang yang dijatuhi pidana mati oleh peradilan di lingkungan Peradilan Umum dan orang-orang baik militer ataupun bukan militer yang dijatuhi pidana mati oleh pengadilan lingkungan Peradilan Militer tidak sesuai lagi dengan perkembangan kemajuan keadaan serta jiwa revolusi Indonesia. ${ }^{19}$ Pelaksanaan pidana mati selanjutnya mengalami pembaharuan dengan dikeluarkannya Peraturan Kepala Kepolisian Republik Indonesia Nomor 12 Tahun 2010 Tentang Tata Cara Pelaksanaan Pidana Mati.

Pelaksanaan pidana mati menurut Undang-Undang 02/Pnps/1964, sebagai berikut: ${ }^{20}$

a. Jika tidak ditentukan lain oleh Menteri Kehakiman, pidana mati dilaksanakan dalam daerah hukum pengadilan yang menjatuhkan putusan dalam tingkat pertama;

b. Kepala Polisi Daerah tempat kedudukan pengadilan tersebut, setelah mendengar nasihat Jaksa Tinggi/Jaksa yang bertanggung jawab untuk pelaksanaannya, menentukan waktu dan tempat pelaksanaan pidana mati;

c. Kepala Polisi Daerah membentuk suatu regu penembak dari Brigade Mobil yang terdiri dari seorang Bintara, 12 orang Tantama, di bawah pimpinan seorang Perwira;

${ }^{19} \mathrm{Hal}$ ini sebagaimana dinyatakan dalam konsiderans menimbang angka 1 UU No. 2/Pnps/1964 Tentang Tata Cara Pelaksanaan Pidana Mati yang Dijatuhkan Oleh Pengadilan di Lingkungan Peradilan Umum dan Militer.

${ }^{20}$ Frans Maramis, 2012, Hukum Pidana Umum dan Tertulis di Indonesia, Rajawali Press, Jakarta, hlm 241-243. 
d. Terpidana dibawa ke tempat pelaksanaan pidana dengan pengawalan polisi yang cukup, dapat disertai oleh seorang perawat rohani, berpakaian sederhana dan tertib;

e. Setiba di tempat pelaksanaan pidana mati, komandan pengawal menutup mata terpidana dengan sehelai kain, kecuali terpidana tidak menghendaki;

f. Terpidana dapat menjalani pidana secara berdiri, duduk atau berlutut, jika dipandang perlu Jaksa Tinggi/Jaksa yang bertanggung jawab dapat memerintahkan supaya terpidana diikat tangan serta kakinya, ataupun diikat kepada sandaran yang khusus dibuat untuk itu;

g. Setelah terpidana siap ditembak, regu penembak dengan senjata sudah diisi menuju tempat yang ditentukan, jarak antara titik dimana terpidana berada dengan regu penembak tidak boleh melebihi 10 meter, dan tidak boleh kurang dari 5 meter;

h. Apabila semua persiapan telah selesai, Jaksa Tinggi/Jaksa yang bertanggung jawab untuk pelaksanaannya, memerintahkan untuk memulai pelaksanaan pidana mati;

i. Dengan menggunakan pedang sebagai isyarat, Komandan Regu Penembak memberi perintah supaya bersiap, kemudian dengan menggerakkan pedangnya ke atas ia memerintahkan regunya untuk membidik pada jantung terpidana, dan dengan menyentakkan pedangnya ke bawah secara cepat, dia memberikan perintah untuk menembak;

j. Apabila setelah penembakan itu, terpidana masih memperlihatkan tanda-tanda bahwa ia belum mati, maka Komandan Regu segera memerintahkan kepada Bintara Regu Penembak untuk melepaskan tembakan pengakhir dengan menekankan ujung laras senjatanya pada kepala terpidana tepat di atas telinganya;

k. Untuk memperoleh kepastian tentang matinya terpidana dapat diminta bantuan seorang dokter;

1. Penguburan diserahkan kepada keluarganya atau sahabat terpidana, kecuali berdasarkan kepentingan umum Jaksa Tinggi/Jaksa yang bertanggung jawab memutuskan lain.

3. Perspektif Hak Asasi Manusia Terhadap Pelaksanaan Pidana Mati di Indonesia

Pelaksanaan pidana mati dengan cara ditembak sampai mati sebagaimana diatur dalam UndangUndang Nomor 02/Pnps/1964 tentang Tata Cara Pelaksanaan Pidana Mati yang Dijatuhkan Pengadilan Dilingkungan Peradilan Umum dan Militer, telah dimohonkan judicial review ke Mahkamah Konstitusi oleh tiga orang terpidana mati dalam kasus bom Bali, yaitu Amrozi bin Nurhasyim, Ali Ghufron bin Nurhasyim alias Muklas, dan Abdul Aziz alias Imam Samudra.

Pemohon dalam permohonannya mengajukan dua jenis judicial review, yaitu permohonan pengujian formil, dan permohonan pengujian materiil atas Undang-Undang Nomor 
02/Pnps/1964 terhadap UUD 1945. Menurut Pemohon Undang-Undang Nomor 02/Pnps/Tahun 1964 tentang Tata Cara Pelaksanaan Pidana Mati Yang Dijatuhkan Oleh Pengadilan di Lingkungan Peradilan Umum dan Militer (Lembaran Negara Tahun 1964 Nomor 38) yang telah ditetapkan menjadi undang-undang dengan Undang-Undang Nomor 5 Tahun 1969, merupakan undang-undang yang pembentukannya tidak memenuhi ketentuan UUD 1945, berdasarkan alasan-alasan sebagai berikut:

a. Bahwa Undang-Undang Nomor 02/Pnps/Tahun 1964, merupakan undang-undang yang pembentukannya didasarkan pada Penetapan Presiden Republik Indonesia;

b. Bahwa Penetapan Presiden a quo, kemudian menjadi undang-undang adalah karena diundangkannya Undang-Undang Nomor 5 Tahun 1969 tentang Pernyataan Berbagai Penetapan Presiden dan Peraturan Presiden sebagai Undang-Undang;

c. Bahwa Penetapan Presiden a quo merupakan Penetapan Presiden yang dimaksud oleh Pasal 2 Undang-Undang Nomor 5 Tahun 1969 yang berbunyi: "Terhitung sejak disahkannya Undang-undang ini, menyatakan Penetapanpenetapan Presiden dan Peraturan-peraturan Presiden sebagaimana termaksud dalam Lampiran IIA dan IIB Undangundang ini, sebagai UndangUndang dengan ketentuan, bahwa materi Penetapan-penetapan Presiden dan Peraturan-Peraturan Presiden tersebut ditampung atau dijadikan bahan bagi penyusunan Undangundang yang baru";

d. Bahwa Undang-Undang Nomor 02/Pnps/1964 juncto UndangUndang Nomor 5 Tahun 1969 adalah undang-undang yang pembentukannya dilakukan dengan cara disahkan oleh Presiden Republik Indonesia dengan disetujui oleh Dewan Perwakilan Rakyat Gotong Royong;

e. Bahwa Dewan Perwakilan Rakyat Gotong Royong (DPR-GR) bukan lembaga perwakilan rakyat sebagaimana dimaksud oleh UUD 1945, karena DPR-GR dibentuk atas dasar Penetapan Presiden dan anggotanya juga diangkat oleh Presiden, sedang Dewan Perwakilan Rakyat (DPR) sebagaimana dimaksud oleh Pasal 19 UUD 1945, anggotanya dipilih melalui pemilihan umum;

f. Bahwa pembentukan undangundang menurut UUD 1945 adalah sebagaimana tersebut dalam Pasal 20 Amandemen UUD 1945, maka pembentukan Undang-Undang Nomor 02/Pnps/1964 juncto Undang-Undang Nomor 5 Tahun 1969 tidak sesuai dengan Pasal 20 tersebut;

g. Bahwa dengan demikian, tentang tata cara pelaksanaan pidana mati dengan cara ditembak hingga mati oleh Regu Penembak, yang selama ini dijalankan di negara kita, Republik Indonesia, merupakan tata cara yang didasarkan pada undangundang yang pembentukannya tidak sesuai dengan UUD 1945;

h. Bahwa merupakan fakta hukum, Undang-Undang Nomor 02/Pnps/1964 yang telah diwajibkan oleh Undang-Undang Nomor 5 Tahun 1969 untuk diadakan perbaikan atau penyempurnaan dalam arti bahwa materi dari penetapan tersebut dijadikan bahan untuk penyusunan undang-undang baru, hingga permohonan diajukan ke 
Mahkamah Konstitusi belum pernah ada perbaikan maupun penyempurnaan terhadap tata cara pelaksanaan hukuman mati di Indonesia.

Terhadap pengujian formil yang diajukan Pemohon, bahwa UndangUndang Nomor 02/Pnps/Tahun 1964, yang telah ditetapkan menjadi undangundang dengan Undang-Undang Nomor 5 Tahun 1969, merupakan undang-undang yang pembentukannya tidak memenuhi ketentuan UUD 1945 , Mahkamah Konstitusi berpendapat sebagai berikut:

a. bahwa dari bentuk hukumnya, memang benar Undang-Undang Nomor 02/Pnps/1964 semula Penetapan Presiden Nomor 2 Tahun 1964 yang tidak dikenal dalam UUD 1945, karena UUD 1945 memang tidak mengatur produk hukum dengan nama Penetapan Presiden, namun hal tersebut telah dikoreksi dengan Undang-Undang Nomor 5 Tahun 1969 atas perintah Ketetapan MPRS Nomor XIX/MPRS/1966 dan Ketetapan MPRS Nomor XXXIX/MPRS/1968. Kedua Ketetapan Majelis Permusyawaratan Rakyat Sementara (MPRS) tersebut berisi perintah untuk melakukan peninjauan kembali terhadap status hukum atas Penetapan Presiden dan Peraturan Presiden. Konsiderans Undang-Undang Nomor 5 Tahun 1969 berbunyi, "bahwa dalam rangka pemurnian produk-produk legislatif yang berbentuk Penetapanpenetapan Presiden dan Peraturanperaturan Presiden yang telah dikeluarkan sejak tanggal 5 Juli 1959" dan "bahwa Penetapan-penetapan Presiden dan Peraturan-peraturan Presiden yang materinya sesuai dengan suara hati nurani rakyat perlu dinyatakan sebagai Undang-undang".
Oleh karena itu, dengan UndangUndang Nomor 5 Tahun 1969, Penetapan Presiden Nomor 2 Tahun 1964 termasuk Penetapan Presiden (Penpres) yang dinyatakan sebagai undang-undang, yaitu menjadi UndangUndang Nomor 02/Pnps/1964, sehingga bentuk hukumnya sudah sesuai dengan UUD 1945. Kata "Pnps" sekedar sebagai tanda bahwa undangundang dimaksud berasal dari Penetapan Presiden. Dinyatakannya beberapa Penetapan Presiden dan Peraturan Presiden, termasuk Penetapan Presiden Nomor 2 Tahun 1964 menjadi undang-undang, menunjukkan bahwa isinya masih sesuai dengan aspirasi rakyat karena merupakan pembaruan terhadap ketentuan Pasal 11 Kitab UndangUndang Hukum Pidana (KUHP);

b. bahwa dari prosedur pembentukannya, Penetapan Presiden Nomor 2 Tahun 1964 tidak sesuai dengan UUD 1945, karena UUD 1945 memang tidak mengenal produk hukum yang bernama "Penetapan Presiden". Akan tetapi, setelah UndangUndnag Nomor 5 Tahun 1969 menyatakan Undang-Undang Nomor 02/Pnps/1964 berlaku, maka prosedur pembentukannya sudah sesuai dengan ketentuan Pasal 5 ayat (1) dan Pasal 20 ayat (1) UUD 1945, yaitu ditetapkan oleh Presiden dengan persetujuan DPR, dalam hal ini DPR GR sebagai DPR yang sah pada awal Orde Baru sebelum DPR hasil pemilihan umum terbentuk. Presiden dan DPR GR yang membentuk Undang-Undang Nomor 5 Tahun 1969 yang menyatakan Penetapan Presiden Nomor 2 Tahun 1964 sebagai Undang-Undang Nomor 
02/Pnps/1964 adalah Presiden dan DPR yang sah pada masa transisi ketatanegaraan dari Orde Lama ke Orde Baru dan telah diterima dan diakui oleh rakyat Indonesia;

c. bahwa Pasal II Aturan Peralihan UUD 1945 sebelum perubahan yang berbunyi, "Segala badan Negara dan peraturan yang ada masih langsung berlaku, selama belum diadakan yang baru menurut Undang-Undang Dasar ini" dan Pasal I Aturan Peralihan UUD 1945 setelah perubahan yang berbunyi, "Segala peraturan perundang-undangan yang ada masih tetap berlaku selama belum diadakan yang baru menurut Undang-Undang Dasar ini”, yang menjadi dasar keberlakuan UndangUndang Nomor 02/Pnps/1964 sampai sekarang, karena undangundang yang baru yang mengatur tentang tata cara pelaksanaan pidana mati belum ada;

d. bahwa dengan demikian, dalil-dalil Pemohon mengenai pengujian formil tidak beralasan, sehingga harus ditolak.

Sedangkan permohonan pengujian materiil, diajukan didasarkan pada ketentuan Pasal 51 ayat (3) huruf b Undang-Undang Mahkamah Konstitusi. Menurut Pemohon Undang-Undang Nomor 02/Pnps/1964 juncto Undang-Undang Nomor 5 Tahun 1969, adalah undangundang yang materi muatan dalam ayat, pasal, dan/atau bagian undang-undang bertentangan dengan UUD 1945 khususnya Pasal 28I ayat (1), berdasarkan alasan-alasan sebagai berikut:

a. Bahwa Pasal 28I ayat (1), berbunyi sebagai berikut: "Hak untuk hidup, hak untuk tidak disiksa, hak kemerdekaan pikiran dan hati nurani, hak beragama, hak untuk tidak diperbudak, hak untuk diakui sebagai pribadi di hadapan hukum, dan hak untuk tidak dituntut atas dasar hukum yang berlaku surut adalah hak asasi manusia yang tidak dapat dikurangi dalam keadaan apa pun";

b. Bahwa Tata Cara Pelaksanaan Pidana Mati dengan cara ditembak hingga mati oleh Regu Penembak sebagaimana ditentukan dalam Undang-Undang Nomor 02/Pnps/1964 juncto UndangUndang Nomor 5 Tahun 1969, adalah penyiksaan terhadap Terpidana;

c. Bahwa Regu Penembak yang diberi tugas untuk mengeksekusi terpidana menurut Undang-Undang Nomor 02/Pnps/1964 juncto UndangUndang Nomor 5 Tahun 1969, diharuskan membidik pada jantung terpidana [Pasal 14 ayat (3)] namun pada Pasal 14 ayat (4) menentukan untuk mengarahkan tembakan pengakhir dengan menekankan ujung laras senjatanya pada kepala terpidana tepat di atas telinganya. Dengan demikian tata cara ini tidak memberikan kepastian akan "tiadanya penyiksaan" dalam proses kematiannya terpidana:

d. Bahwa meskipun seorang warga negara Indonesia itu statusnya adalah Terpidana maka menurut UUD 1945, khususnya Pasal 28I ayat (1), tetap dijamin hak asasi manusianya, sehingga penyiksaan terhadapnya dengan menggunakan tata cara pelaksanaan hukuman mati berdasarkan Undang-Undang Nomor 02/Pnps/1964 juncto Undang-Undang Nomor 5 Tahun 1969, merupakan pelanggaran atas hak konstitusionalnya, dengan demikian Undang-Undang Nomor 02/Pnps/1964 juncto UndangUndang Nomor 5 Tahun 1969 
materinya jelas bertentangan dengan UUD 1945.

Terhadap pengujian materiil Undang-Undang Nomor 02/Pnps/1964, khususnya Pasal 1, Pasal 14 ayat (3) dan ayat (4) terhadap Pasal 28I ayat (1) UUD 1945 yang diajukan Pemohon, Mahkamah Konstitusi memberi pendapat sebagai berikut:

a. bahwa ukuran yang harus dipedomani tentang penyiksaan harus mengacu kepada rumusan yang dianut dalam instrumen hukum Hak Asasi Manusia (selanjutnya disebut HAM) yang berlaku di Indonesia, sebagaimana termuat dalam Undang-Undang Nomor 39 Tahun 1999 tentang Hak Asasi Manusia dan Undang-Undang Nomor 5 Tahun 1998 tentang Pengesahan Convention Against Torture and Other Cruel, Inhuman or Degrading Treatment or Punishment (Konvensi Menentang Penyiksaan dan Perlakuan atau Penghukuman Lain yang Kejam, Tidak Manusiawi, atau Merendahkan Martabat Manusia). Pasal 1 angka 4 Undang-Undang 39 Tahun 1999 tentang Hak Asasi Manusia menyatakan bahwa penyiksaan adalah "setiap perbuatan yang dilakukan dengan sengaja, sehingga menimbulkan rasa sakit atau penderitaan yang hebat, baik jasmani maupun rohani, pada seseorang untuk memperoleh pengakuan atau keterangan dari seseorang atau dari orang ketiga, dengan menghukumnya atas suatu perbuatan yang telah dilakukan atau diduga telah dilakukan oleh seseorang atau pihak ketiga, atau mengancam atau memaksa seseorang atau orang ketiga, atau untuk suatu alasan yang didasarkan pada setiap bentuk diskriminasi, apabila rasa sakit atau penderitaan tersebut ditimbulkan oleh, atas hasutan dari, dengan persetujuan atau sepengetahuan siapapun dan/atau pejabat publik". Definisi penyiksaan tersebut telah merujuk dan mengutip sepenuhnya Pasal 1 Convention Against Torture and Other Cruel, Inhuman or Degrading Treatment or Punishment yang telah diratifikasi tersebut di atas.

b. bahwa alasan Indonesia menjadi negara pihak dalam konvensi yang menentang penyiksaan tersebut di atas, antara lain disebutkan: (1) Pancasila sebagai falsafah dan pandangan hidup bangsa Indonesia dan UUD 1945 sebagai sumber dan landasan hukum nasional, menjunjung tinggi harkat dan martabat manusia seperti tercermin dalam Sila Kemanusiaan yang Adil dan Beradab. Asas ini merupakan amanat konstitusional bahwa bangsa Indonesia bertekad untuk mencegah dan melarang segala bentuk penyiksaan, sesuai dengan isi konvensi; (2) dalam rangka pengamalan Pancasila dan pelaksanaan UUD 1945, Indonesia pada dasarnya telah menetapkan peraturan perundang-undangan yang langsung mengatur pencegahan dan pelarangan segala bentuk penyiksaan yang tidak manusiawi dan merendahkan martabat manusia. Namun, perundang-undangan itu karena belum sepenuhnya sesuai dengan konvensi, masih perlu disempurnakan.

c. bahwa rasa sakit yang disebut sebagai penyiksaan, bukanlah sesuatu yang terjadi secara alamiah dan wajar, melainkan dilakukan secara sengaja dan melawan hukum untuk tujuan tertentu di luar kehendak mereka yang disiksa. Rasa sakit yang timbul secara alamiah seperti yang dialami oleh setiap 
wanita yang melahirkan dan orang yang menjalani operasi karena tujuan medis tertentu tidaklah termasuk dalam kategori penyiksaan. Terlebih-lebih lagi, rasa sakit yang timbul dan melekat dalam pelaksanaan pidana mati adalah sesuatu yang tidak dapat dihindari akan timbul dalam tiap cara pelaksanaan pidana mati. Yang terjadi, sesungguhnya bukan karena pemilihan tata cara pelaksanaannya, melainkan melekat dalam setiap pidana mati yang dijatuhkan hakim, yang oleh Mahkamah telah dinyatakan sebagai sesuatu yang konstitusional. Konvensi secara tegas menyatakan bahwa rumusan penyiksaan yang diatur dalam Konvensi tidak meliputi rasa sakit atau penderitaan yang semata-mata timbul dari, melekat pada, atau diakibatkan oleh satu sanksi hukum yang berlaku.

d. bahwa akan tetapi dalam pelaksanaan pidana mati, Mahkamah berpendapat, ukuran yang juga harus dipedomani adalah untuk menghindari pelaksanaan pidana mati yang menimbulkan penderitaan terpidana tersebut secara berkepanjangan, dan juga siksaan yang dirasakan, diukur bukan hanya dari sisi subjektif terpidana sendiri, melainkan juga dari sisi objektif masyarakat, yang akan melihat pokok persoalan demikian dari hal-hal berikut:

1). bahwa ukuran dalam menentukan apakah suatu tata cara pelaksanaan pidana mati merupakan sesuatu yang kejam, tidak manusiawi, dan tidak biasa, dapat dinilai dari pelaksanaan, yaitu: (i) jika cara yang dilakukan menimbulkan penderitaan yang panjang dan tidak diperlukan dalam menimbulkan kematian; (ii) bertentangan dengan ukuran kesusilaan yang dianut dalam masyarakat; dan (iii) tidak menjaga dan mempertahankan harkat martabat terpidana sebagai manusia;

2). bahwa pelaksanaan pidana mati dengan cara ditembak hingga mati tidak selalu terjadi sekaligus dalam "satu kali tembakan", namun ada kalanya dilakukan dengan tembakan pengakhir, karena tidak ada jaminan penembakan sekali oleh regu tembak dapat menimbulkan kematian bagi terpidana. Dengan demikian, tetap ada dua kemungkinan bahwa penembakan yang dilakukan oleh regu tembak dapat langsung mematikan dan juga dapat tidak langsung mematikan, hal mana telah menyebabkan bahwa tata cara yang dilakukan dapat menimbulkan penderitaan yang tidak diperlukan oleh terpidana untuk menimbulkan kematiannya. Keterangan Saksi Pastor Charlie Burrows, yang menerangkan bahwa Terpidana Antonius membutuhkan waktu 7 (tujuh) menit mengerang kesakitan sejak tembakan dilakukan ke arah jantung baru dinyatakan meninggal, menimbulkan pertanyaan apakah sesuai dengan ukuran yang diutarakan di atas atau ada tata cara lain yang lebih memenuhi ukuran untuk menghindarkan penderitaan yang tidak diperlukan untuk menimbulkan kematian;

3). bahwa keterangan para ahli yang diajukan oleh Pemohon telah menyatakan adanya cara-cara 
pelaksanaan pidana mati lainnya yang dikenal, yaitu dengan cara dipancung, dikursi listrik, disuntik mati, digantung sampai mati, dan khusus menurut hukum Islam dikenal juga dengan hukuman dirajam sampai mati. Dari keterangan para ahli tersebut diketahui bahwa pidana mati dengan disuntik mati yang dilakukan dengan didahului pembiusan, kalau dilakukan oleh orang yang ahli tidak menimbulkan penderitaan yang tidak perlu, sedangkan hukuman pancung, kalau dilakukan di tempat yang tepat akan menimbulkan kematian yang segera, karena dalam waktu 7 (tujuh) sampai dengan 12 (dua belas) detik berhentinya darah ke otak akan menyebabkan kematian. Demikian juga hukuman gantung, kalau letak tali tepat di batang leher dan berat badan terpidana cukup, maka dampak kematian juga terjadi secara cukup cepat;

4). bahwa akan tetapi meskipun perkembangan ilmu pengetahuan dan teknologi perlu dimanfaatkan dalam penegakan hukum, khususnya dalam tata cara pelaksanaan pidana mati, namun berkurangnya penderitaan atau rasa sakit itu sendiri bukanlah merupakan alasan yang cukup dalam menilai konstitusionalitas norma dalam UU 02/Pnps/1964 tersebut, karena pelaksanaan pidana mati dengan cara ditembak sampai mati juga sesungguhnya dapat berlangsung secara cepat, sesuai dengan keterangan ahli, apabila tembakan tepat mengenai jantung terpidana. Sejalan dengan itu, berdasarkan keterangan para ahli yang didengar dalam persidangan tidak ada satu cara pun yang menjamin pelaksanaan pidana mati yang tidak menimbulkan rasa sakit atau kematian dengan cepat;

5). bahwa selain itu, baik pidana mati dengan cara dipancung, digantung, maupun ditembak mati dapat menimbulkan efek kematian secara cepat jika dilakukan dengan tepat. Akan tetapi, cara pelaksanaan pidana mati haruslah mempertimbangkan harkat dan martabat terpidana mati. Menurut Mahkamah, pidana mati yang dilakukan dengan ditembak secara tepat dapat menimbulkan kematian cepat dengan tetap menjaga harkat dan martabat terpidana mati.

Akhirnya dalam bagian penutup permohonan yang diajukan oleh Pemohon kepada Mahkamah Konstitusi, Pemohon memohon agar Mahkamah Konstitusi mengabulkan semua permohonan Pemohon, selengkapnya sebagai berikut:

a. Mengabulkan permohonan Pemohon untuk seluruhnya;

b. Menyatakan Undang-Undang Nomor 02/Pnps/Tahun 1964 tentang Tata Cara Pelaksanaan Pidana Mati Yang Dijatuhkan Oleh Pengadilan di Lingkungan Peradilan Umum dan Militer (Lembaran Negara Tahun 1964 Nomor 38) yang telah ditetapkan menjadi undang-undang dengan UndangUndang Nomor 5 Tahun 1969 tentang Pernyataan Berbagai Penetapan Presiden dan Peraturan Presiden Sebagai Undang-Undang (Lembaran Negara Tahun 1969 Nomor 36), merupakan undang- 
undang yang pembentukannya tidak memenuhi ketentuan UndangUndang Dasar Negara Republik Indonesia Tahun 1945;

c. Menyatakan Undang-Undang Nomor 02/Pnps/Tahun 1964 tentang Tata Cara Pelaksanaan Pidana Mati yang dijatuhkan oleh Pengadilan di Lingkungan Peradilan Umum dan Militer (Lembaran Negara Tahun 1964 Nomor 38) yang telah ditetapkan menjadi undang-undang dengan UndangUndang Nomor 5 Tahun 1969 tentang Pernyataan Berbagai Penetapan Presiden dan Peraturan Presiden Sebagai Undang-Undang (Lembaran Negara Tahun 1969 Nomor 36) tersebut tidak mempunyai kekuatan hukum mengikat;

d. Atau bilamana Mahkamah berpendapat lain sudilah kiranya memberikan putusan yang seadiladilnya.

Terhadap petitum permohonan yang diajukan Pemohon sebagaimana tersebut di atas, Mahkamah Konstitusi dalam amar mengadili Putusan Nomor 21/PUU-VI/2008 menyatakan permohonan Pemohon baik mengenai pengujian formil maupun pengujian materiil ditolak untuk seluruhnya. Berdasarkan bunyi amar putusan mengadili Mahkamah Konstitusi sebagaimana tersebut dalam Putusan Nomor 21/PUU-VI/2008, maka dapat disimpulkan pelaksanaan pidana mati dengan cara ditembak sampai mati sebagaimana diatur dalam UndangUndang Nomor 02/Pnps/1964 tidak bertentangan dengan UUD 1945 khususnya Pasal 28I ayat (1). Mahkamah Konstitusi dalam konklusi putusannya menyatakan bahwa rasa sakit yang dialami terpidana mati merupakan konsekuensi logis yang melekat dalam proses kematian sebagai akibat pelaksanaan pidana mati sesuai dengan tata cara yang berlaku, sehingga tidak termasuk kategori penyiksaan terhadap diri terpidana mati. Bahkan lebih lanjut menurut Mahkamah Konstitusi, bahwa dari berbagai alternatif tentang tata cara pelaksanaan pidana mati selain cara ditembak, seperti digantung, dipenggal pada leher, disetrum listrik, dimasukkan ke dalam ruang gas, dan disuntik mati, semuanya menimbulkan rasa sakit meskipun gradasi dan kecepatan kematiannya berbeda-beda. Tidak ada satu cara pun yang menjamin tiadanya rasa sakit dalam pelaksanaannya, bahkan semuanya mengandung risiko terjadinya ketidaktepatan dalam pelaksanaan yang menimbulkan rasa sakit.

Putusan Mahkamah Konstitusi Nomor 21/PUU-VI/2008 memperoleh kekuatan hukum tetap sejak selesai diucapkan dalam sidang pleno terbuka untuk umum. Putusan MK bersifat final, artinya langsung memperoleh kekuataan hukum tetap sejak diucapkan dan tidak ada upaya hukum yang dapat ditempuh. Dengan demikian Putusan Mahkamah Konstitusi Nomor 21/PUU-VI/2008, tidak hanya mengikat pihak-pihak yang mengajukan permohonan judicial review, yaitu pihak yang berpendirian bahwa pelaksanaan pidana mati dengan cara ditembak sampai mati sebagaimna diatur dalam Undang-Undang Nomor 02/Pnps/1964 bertentangan dengan UUD 1945. Tetapi juga mengikat semua komponen bangsa, seharusnya dengan adanya putusan tersebut dapat mengakhiri perdebatan soal legalitas pelaksanaan pidana mati di Indonesia. Semua pihak seharusnya mempunyai pandangan yang sama, bahwa pelaksanaan pidana mati dengan cara 
ditembak sampai mati tidak bertentangan dengan UUD 1945.

Pandangan Mahkamah Konstitusi yang menyatakan pelaksanaan pidana mati tidak bertentangan dengan UUD 1945, sejatinya dapat diterima. Patut pula dicatat sebagai perhatian, pernyataan MPR yang tertuang dalam buku Panduan Pemasyarakatan UUD 1945 dan Ketetapan MPR RI, yang diterbitkan oleh Sekretariat Jenderal MPR RI tahun 2012. Bahwa dalam bab tentang HAM (Bab XA UUD 1945) terdapat dua pasal yang saling berkaitan erat, yaitu Pasal 28I dan Pasal 28J. Keberadaan Pasal 28J dimaksudkan untuk mengantisipasi sekaligus membatasi Pasal 28I. ${ }^{21}$

Pasal 28I mengatur beberapa HAM yang tidak dapat dikurangi dalam keadaan apapun, termasuk di dalamnya hak untuk tidak disiksa. Sedangkan Pasal 28J memberikan pembatasan yang ditetapkan dengan undangundang dan untuk menjamin pengakuan serta penghormatan atas hak dan kebebasan orang lain, dan untuk memenuhi tuntutan yang adil sesuai dengan pertimbangan moral, nilai-nilai agama, keamanan, dan ketertiban umum dalam suatu masyarakat demokratis.

Sungguhpun Mahkamah Konstitusi telah menyatakan dalam Putusan Nomor 21/PUU-VI/2008, bahwa pelaksanaan pidana mati dengan ditembak sampai mati sebagaimana diatur dalam Undang-Undang nomor 02/Pnps/1964 tidak bertentangan dengan UUD 1945, yang dengan demikian dapat diartikan bahwa pelaksanaan pidana mati dengan ditembak sampai mati tidak melanggar HAM khususnya hak untuk tidak disiksa sebagaimana diatur dalam Pasal

${ }^{21}$ MPR RI, Panduan..., hlm 181.
28I ayat (1) UUD 1945. yang diakui dan dinyatakan sebagai hak yang tidak dapat dikurangi dalam keadaan apapun. Namun demikian upaya untuk menemukan bentuk pelaksanaan pidana mati yang lebih cepat menimbulkan kematian terpidana, dan dapat mengurangi jangka waktu lamanya rasa sakit yang harus dialami oleh terpidana tetap harus dilakukan.

\section{Penutup}

1. Cara pelaksanaan pidana mati di Indonesia dilakukan dengan berpedoman pada aturan hukum yang telah ada. Pasal 11 KUHP menyatakan bahwa pidana mati dijalankan oleh algojo ditempat penggantungan, dengan menggunakan sebuah jerat dileher terpidana dan mengikatkan jerat itu pada tiang penggantungan dan menjatuhkan papan tempat orang itu berdiri. Ketentuan Pasal 11 KUHP dicabut oleh Undang-Undang Nomor 02/Pnps/1964 juncto Undang-Undang Nomor 5 Tahun 1969 Tentang Tata Cara Pelaksanaan Pidana Mati yang Dijatuhkan oleh Pengadilan di Lingkungan Pengadilan Umum dan Militer. Dalam Pasal 1 dinyatakan bahwa pelaksanaan pidana mati yang dijatuhkan oleh pengadilan di lingkungan Peradilan Umum atau Peradilan Militer dilakukan dengan ditembak sampai mati.

2. Berdasarkan Putusan Mahkamah Konstitusi Nomor 21/PUUVI/2008, yang menyatakan bahwa pelaksanaan pidana mati dengan ditembak sampai mati sebagaimana diatur dalam Undang-Undang nomor 02/Pnps/1964 tidak 
bertentangan dengan UUD 1945, yang dengan demikian dapat diartikan bahwa pelaksanaan pidana mati dengan ditembak sampai mati tidak melanggar HAM khususnya hak untuk tidak disiksa sebagaimana diatur dalam Pasal 28I ayat (1) UUD 1945. Meskipun pelaksanaan pidana mati dengan cara ditembak, memang menimbulkan rasa sakit yang melekat di dalam pelaksanaan pidana mati sebagai akibat putusan hakim yang sah. Namun rasa sakit yang dialami oleh terpidana tidak dapat dikatakan sebagai suatu bentuk penyiksaan terhadap terpidana. Rasa sakit dalam pelaksanaan pidana mati akan tetap dirasakan oleh terpidana, walaupun dilakukan dengan cara yang berbeda selain dengan ditembak sampai mati.

\section{Daftar Pustaka}

Abidin Farid, A.Z. dan A. Hamzah. Bentuk-Bentuk Khusus Perwijudan Delike (Percobaan, Penyertaan, dan Gabungan Delik) dan Hukum Penitensier. Jakarta. PT RajaGrafindo Persada.2006.

Ali, Achmad. Menguak Realitas Hukum Rampai Kolom \& Artikel Pilihan Dalam Bidang Hukum. Jakarta. Kencana. 2008.

Anwar, Yesmil. Adang. Pembaharuan Hukum Pidana Reformasi Hukum Pidana. Jakarta. PT Grasindo. 2008.

Arba'i, Yon Artiono. Aku Menolak Hukuman Mati Telaab Atas Penerapan Pidana Mati. Jakarta.
KPG (Kepustakaan Populer Gramedia). 2012.

Arief, Barda Nawawi. Bunga Rampai Kebijakan Hukum Pidana. Bandung. PT Citra Aditya Bakti. 2002.

Masalah Penegakan Hukum dan Kebijakan Hukum Pidana dalam Penanggulangan Kejahatan. Jakarta. Kencana. 2007.

------. Pembaharuan Hukum Pidana dalam Perspektif Kajian Perbandingan. Bandung. Citra Aditya Bakti. 2005.

Asshiddiqie, Jimly. Pembaharuan Hukum Pidana Indonesia. Bandung. Angkasa. 1995.

------. Hukum Tata Negara dan PilarPilar Demokrasi. Jakarta. Sinar Grafika. 2012.

Chazawi, Adami. Pelajaran Hukum Pidana 1 Stelsel Pidana Tindak Pidana Teori-teori Pemidanaan \& Batas Berlakunya Hukum Pidana. Jakarta. PT RajaGrafindo Persada. 2007.

Danil, Elwi. Korupsi Konsep, Tindak Pidana, dan Pemberantasannya. Jakarta. PT RajaGrafindo Persada. 2014.

Hamidi, Jazim. dan Lutfi, Mustafa. Civic Education Antara Realitas Politik. dan Implementasi Hukumnya. Jakarta. Gramedia Pustaka utama. 2010.

Kanter, E.Y. dan S.R. Sianturi. AsasAsas Hukum Pidana di Indonesia 
dan Penerapannya. Jakarta. Storia Grafika. 2002.

Lubis, Todung Mulya. Alexander Lay. Kontroversi Hukuman Mati Perbedaan Pendapat Hakim Konstitusi. Jakarta. Kompas. 2009.

Manan, Munafrizal. Penemuan Hukum oleh Mabkamah Konstitusi. Bandung. Mandar Maju. 2012.

Maramis, Frans. Hukum Pidana Umum dan Tertulis di Indonesia. Jakarta. Rajawali Press. 2012.

MPR RI. Panduan Pemasyarakatan Undang-Undang Dasar Negara Republik Indonesia Tabun 1945 Sesuai dengan Urutan Bab Pasal dan Ayat. Jakarta. Sekretariat Jenderal MPR RI. 2005.

Moeljatno. Azaz-Azaz Hukum Pidana. Jakarta. Bina Aksara. 1983.

Muhammad, Abdulkadir. Hukum dan Penelitian Hukum. Bandung. PT Citra Aditya Bakti. 2004.

Muladi (Editor). Hak Asasi Manusia Hakekat Konsep dan Implikasinya dalam Perspektif Hukum dan Masyarakat. Bandung. Refika Aditama. 2009.

Nurdjana, IGM. Sistem Hukum Pidana dan Bahaya Laten Korupsi Perspektif Tegaknya Keadilan Melawan Mafia Hukum. Yogyakarta. Pustaka Pelajar. 2010.

Nurus Zaman. Politik. Hukum Pengadaan Tanab Antara Kepentingan Umum dan Perlindungan Hak Asasi Manusia. Bandung, Refika Aditama. 2016.
Prasetyo, Teguh. Kriminalisasi Dalam Hukum Pidana. Bandung. Nusamedia. 2010,

Prakoso, Djoko. Masalah pidana Mati (Soal Jawab). Jakarta. Bina Aksara. 1987.

Prakoso, Djoko. Nurwachid. Studi Tentang Pendapat-Pendapat Mengenai Efektivitas Pidana Mati di Indonesia Dewasa Ini. Jakarta. Ghalia Indonesia. 1985.

Poernomo, Bambang. Hukum Pidana Kumpulan Karangan Ilmiah. Jakarta. Bina Aksara. 1982.

Prodjodikoro, Wirjono. Asas-Asas Hukum Pidana di Indonesia. Bandung. Refika Aditama. 2003.

Rahardjo, Satjipto. Hukum dan Masyarakat. Bandung. Angkasa. 1986.

Rukmono, Bambang Sugeng. Hakikat Pelaksanaan Hukuman Mati Ditinjan Dari Perspektif Hak Asasi Manusia. Jakarta. PT RajaGrafindo Persada. 2016.

Sahetapy, J.E. Ancaman Pidana Mati Terbadap Pembunuban Berencana. Bandung. Alumni. 1979.

Salmi, Ahkiar. Eksistensi Hukuman Mati. Jakarta. Aksara Persada Press. 1985.

Sholehuddin, M. Sistem Sanksi Dalam Hukum Pidana Ide Dasar Double Track System \& Implementasinya. Jakarta. PT RajaGrafindo Persada. 2007. 
Sianturi, S.R., Mompang L. Panggabean. Hukum Penitensia di Indonesia. Jakarta. Alumni AhaemPetehaem. 1996.

Soekanto, Soerjono. Pengantar Penelitian Hukum. Jakarta. UI Press. 1984.

------, Faktor-faktor yang Mempengarubi Penegakan Hukum. Jakarta. PT Raja Grafindo Persada. 2008,

Soesilo, R. Pokok-Pokok Hukum Pidana Peraturan Umum dan Delik-Delik Khusus. Bogor. Politeia. 1984.

Sudarto. Hukum Pidana dan Perkembangan Masyarakat Kajian Terhadap Pembaharuan Hukum Pidana. Bandung. Sinar Baru. 1983.

-------. Hukum dan Hukum Pidana. Bandung. Alumni. 1986.

Sunggono, Bambang. Metodologi Penelitian Hukum. Jakarta. PT Raja Grafindo Persada. 2005.

Suparni, Niniek. Eksistensi Pidana Denda dalam Sistem Pidana dan Pemidanaan. Jakarta. Sinar Grafika. 1996.

Tim Imparsial. Menggugat Hukuman Mati Di Indonesia. Jakarta. Imparsial. 2010.

Tongat. Dasar-Dasar Hukum Pidana Indonesia Dalam Perspektif Pembaharuan. Malang. UMM Press. 2008.

Waluyo, Bambang. Pidana dan Pemidanaan. Jakarta. Sinar Grafika. 2000.
Zaman, Nurus. Politik Hukum Pengadaan Tanab Antara Kepentingan Umum dan Perlindungan Hak Asasi Manusia. Bandung. Refika Aditama. 2016.

